\title{
Effects of the axonal leak conductance on energy and information Patrick Crotty* and Jeffrey Seely
}

Address: Department of Physics and Astronomy, Colgate University, Hamilton, NY 13346, USA

Email: Patrick Crotty* - pcrotty@colgate.edu

* Corresponding author

from Seventeenth Annual Computational Neuroscience Meeting: CNS*2008

Portland, OR, USA. 19-24 July 2008

Published: II July 2008

BMC Neuroscience 2008, 9(Suppl I):P4I doi: I0.1 I86/I47I-2202-9-SI-P4I

This abstract is available from: http://www.biomedcentral.com/I47I-2202/9/SI/P4 I

(C) 2008 Crotty and Seely; licensee BioMed Central Ltd.

Ionic "leak" conductances which have little to no dependence on the membrane potential have long been known to exist in neurons and play a critical role in stabilizing them electrically. Hodgkin and Huxley measured a small total leak conductance $\left(G_{L}\right)$ of approximately $0.3 \mathrm{mS} / \mathrm{cm}^{2}$ in the squid giant axon in addition to much larger voltagegated $\mathrm{Na}^{+}$and $\mathrm{K}^{+}$conductances [1]. Potassium leak cur-

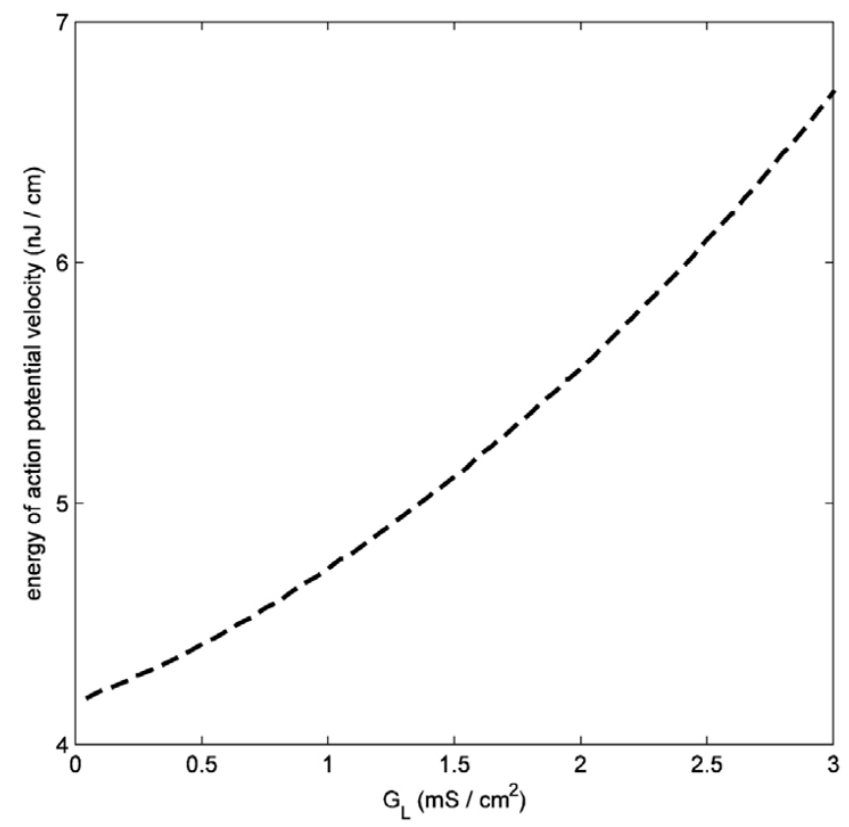

Figure I

The metabolic energy of the AP velocity does not show a minimum as a function of $G_{L}$ in the Hodgkin-Huxley model. rents may flow through several $\mathrm{K}^{+}$channels simultaneously [2], while a recent study [3] has identified a possible subfamily of $\mathrm{Na}^{+}$leak channels.

In this study, we use a computational model of the squid giant axon to explore the dependence of metabolic energy consumption and information rates on $G_{L}$. Energy and

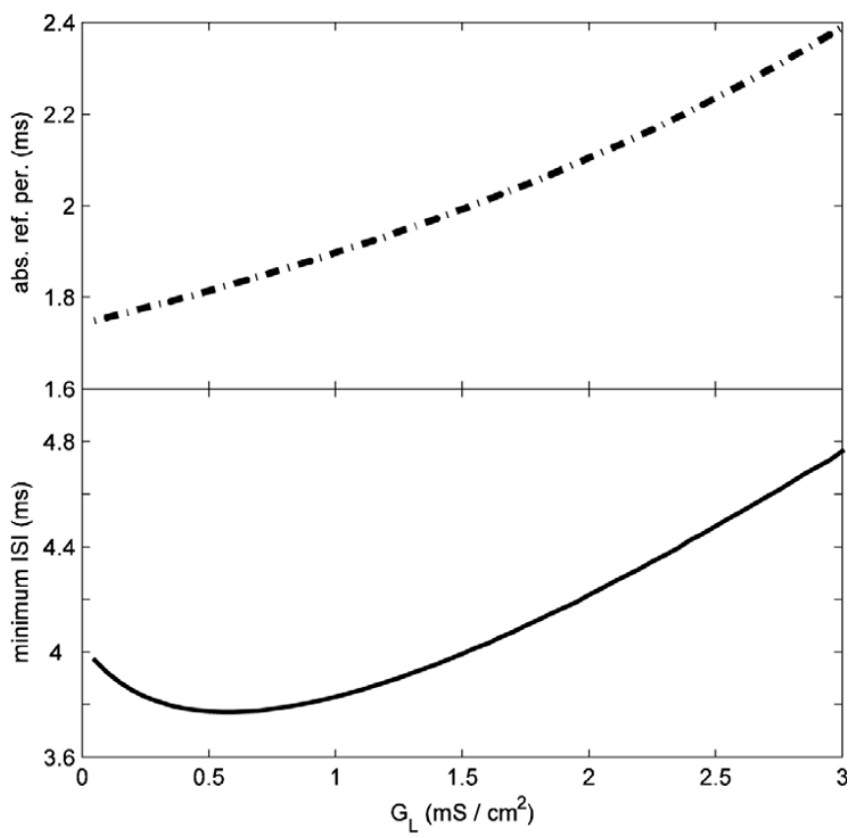

Figure 2

The minimum interspike interval (ISI) does show a minimum near the experimental value. 
information, and more generally whether and how biological nervous systems are optimized for these quantities, have been the focus of much computational work in recent years. In a previous study [4], it was shown that the experimentally measured combined voltage-gated and leak conductances are at or near the optimal values that minimize the metabolic energy associated with the velocity of the action potential (AP). Here, we vary the leak conductance separately from the other conductances to see whether it is itself at an optimum for energy or information. As previously, we assume a prior constraint on the AP velocity and vary both the leak conductance and diameter so as to maintain this velocity.

While we do not find a minimum for the action potential energy as a function of $G_{L}$ (Fig. 1), we do find one for the minimum interspike interval between two APs such that jitter, or the distortion of an interval between two successive APs, is below a certain limit (Fig. 2). This optimal value for $G_{L}$ is fairly close to the measured value of $0.3 \mathrm{mS} /$ $\mathrm{cm}^{2}$, suggesting that nervous systems are optimized for information rates.

\section{References}

I. Hodgkin AL, Huxley AF: A quantitative description of membrane current and its application to conduction and excitation in nerve. J Physiol 1952, I 17:500-544.

2. Heurteaux C, Guy N, Laigle C, Blondeau N, Duprat F, Mazzuca M, Lang-Lazdunski L, Widmann C, Zanzouri M, Romey G, Lazdunski M: TREK-I, a $\mathrm{K}^{+}$channel involved in neuroprotection and general anesthesia. EMBO J 2004, 23:2684-2695.

3. Lu B, Su Y, Das S, Liu J, Xia J, Ren D: The neuronal channel NALCN contributes resting sodium permeability and is required for the normal respiratory rhythm. Cell 2007, | 29:37|-383.

4. Crotty P, Sangrey T, Levy WB: Metabolic energy cost of action potential velocity. J Neurophysiol 2006, 96:1237-1246.
Publish with Biomed Central and every scientist can read your work free of charge

"BioMed Central will be the most significant development for disseminating the results of biomedical research in our lifetime. " Sir Paul Nurse, Cancer Research UK

Your research papers will be:

- available free of charge to the entire biomedical community

- peer reviewed and published immediately upon acceptance

- cited in PubMed and archived on PubMed Central

- yours - you keep the copyright

Submit your manuscript here:

http://www.biomedcentral.com/info/publishing_adv.asp 